\title{
Vulnerability of developing brain
}

\section{8*. Regional acetylcholinesterase activity in the brains of adult rats undernourished in early life}

\author{
BY B. P. F. ADLARD AND J. DOBBING \\ Department of Child Health, University of Manchester, \\ Clinical Sciences Building, York Place, Manchester $M_{1} 3 \circ f 7$ \\ (Received 4 November 1971 - Accepted 5 Fanuary 1972) $^{2}$
}

\begin{abstract}
I. Acetylcholinesterase (AChE; EC 3.1 .1 .7 ) activity was determined in the forebrain, cerebellum and brain stem of I 2-week-old rats having different nutritional histories. One group (control) was well fed throughout life. A second group (rehabilitated) was undernourished during the foetal and suckling periods, but fed $a d l i b$. after weaning. A third group (undernourished) was subjected to nutritional growth retardation throughout life.

2. AChE activity per $\mathrm{g}$ wet weight in $\mathbf{r} 2$-week-old animals was in general in the order undernourished > rehabilitated > control, whether measured in whole homogenates or in crude mitochondrial fractions. In contrast, $\mathrm{AChE}$ activity per region was in the reverse order.

3. It is concluded that undernutrition during the period of most rapid brain growth results in a lasting change in both the concentration and total activity of $\mathrm{AChE}$ in the brain.
\end{abstract}

A reduced rate of bodily growth during the brain-growth spurt alters the developmental profiles of certain enzymes (Chase, Dorsey \& McKhann, 1967; Adlard \& Dobbing, I $97 \mathrm{I} a$ ) and results in permanent deficits and distortions of brain composition and structure (Dobbing, 1968, 1972). There is also delay in the appearance of simple reflexes in undernourished suckling rats (Smart \& Dobbing, 1971). One most important question is whether a deficit in a brain component in a young undernourished animal is permanent or is curable on 'rehabilitation' by feeding ad lib. to adulthood.

Previous experiments have shown reduced acetylcholinesterase (AChE; EC 3. I . I .7) concentrations in 21-d-old undernourished rats (Adlard \& Dobbing, 1972), but raised concentrations in previously undernourished, rehabilitated adult rats (Adlard \& Dobbing, I97 $b$ ). These studies have now been extended in two ways, by examining the enzyme $(a)$ in mature animals undernourished throughout life, and $(b)$ in separate regions of the brains of control, rehabilitated and continuously undernourished animals.

\section{METHODS}

Animals. Rats of a black and white hooded strain were used. All received water ad $l i b$. and a good quality diet (Breeding Diet for Rats and Mice, supplied by Oxoid Ltd, Southwark Bridge Road, London $\mathrm{SE}_{\mathrm{I}}$ ) either $a d l i b$. or in restricted quantity where indicated. The day of mating was determined by examination of vaginal lavages for sperm. Litters were reduced to eight animals at birth. Any litters falling below six in number were discarded. Young were weaned at $25 \mathrm{~d}$ of age. Control animals were

\footnotetext{
* Paper no. 7 : Expl Neurol. (1971), 32, 439.
} 
offspring of well-fed mothers and received food $a d$ lib. Foetal and suckling undernutrition was produced by underfeeding the mother from the 7 th day of gestation. Mothers reccived $10 \mathrm{~g}$ food/d, during pregnancy, $15 \mathrm{~g} / \mathrm{d}$ in the ist postnatal week, $20 \mathrm{~g} / \mathrm{d}$ in the 2 nd postnatal week and $25 \mathrm{~g} / \mathrm{d}$ thereafter. (These values represent approximately $50 \%$ of the normal maternal food intake during pregnancy and lactation.) At weaning, the growth-retarded young were given food either $a d$ lib. (rehabilitated group) or a restricted daily quantity of food $(3.5-5 \mathrm{~g})$ allowing growth to a body-weight of approximately $60 \mathrm{~g}$ at $\mathrm{i} 2$ weeks of age (undernourished group).

Tissue preparation. All animals were killed at $\mathrm{I} 2$ weeks of age by an overdose of diethyl ether. There were eight male rats in each group. Controls came from three litters, rehabilitated animals from five litters and undernourished animals from six litters. The brain was dissected into forebrain (omitting olfactory lobes), cerebellum and brain stem, the latter being separated from forebrain superior to the corpora quadrigemina. The right forebrain and the whole cerebellum were immediately deep frozen. The left forebrain and the whole brain stem were separately homogenized (clearance $0.15 \mathrm{~mm}$, IO strokes at $1200 \mathrm{rev} / \mathrm{min}$ ) in 9 volumes of ice-cold $0.32 \mathrm{M}$ sucrose - I mmol-EDTA ( $\left.\mathrm{pH}_{7} \cdot 4\right)$ and a crude mitochondrial fraction was prepared by the subcellular fractionation technique of Cuzner \& Davison (I968). Enzyme assays on deep-frozen tissue were carried out within 3 weeks of killing using $2 \cdot 5 \%(\mathrm{w} / \mathrm{v})$ homogenates in $0.32 \mathrm{M}$-sucrose - I mmol-EDTA ( $\mathrm{pH} 7.4$ ).

Enzyme assays. Fresh tissue was used for determination of forebrain and brain stem AChE. Dcep-frozen tissue was used for determination of cerebellar AChE and forebrain ATPase (ATP phosphohydrolase; $E C_{3} .6 .1 .3$ ) and fumarate hydratase (L-malate hydro-lyase, $E C_{4}$.2.I.2); it was established that storage did not affect the activity of these enzymes. AChE was determined at $25^{\circ}$ in $0.05 \mathrm{M}$-tris $-\mathrm{HCl}$ buffer $\left(\mathrm{pH}_{7} \cdot 4\right)$ (Ellman, Courtney, Andres \& Featherstone, 196I). ATPase was assayed in the presence of $\mathrm{Na}^{+}, \mathrm{K}^{+}$and $\mathrm{Mg}^{2+}$ according to Swanson, Bradford \& Mcllwain (1964). Fumarate hydratase was used as a mitochondrial marker (Fonnum, I968) and was determined at $25^{\circ}$ in $0.05 \mathrm{M}$-tris- $\mathrm{HCl}$ buffer ( $\mathrm{pH} 7.4$ ) according to Racker ( $195^{\circ}$ ). Enzyme activities were expressed as units per wet weight of tissue, units per mg protein (Lowry, Rosebrough, Farr \& Randall, 195I) or units per brain region.

\section{RESULTS}

Body-and brain weights. The growth curves from weaning for the three groups of animals are given in Fig. I. At weaning, growth-retarded animals had a mean bodyweight deficit of $65 \%$. Rehabilitation to 12 weeks of age reduced this deficit to $39 \%$, but continuing undernutrition increased it to $84 \%$. Undernutrition affected the weight of the cerebellum more than that of other regions (Table I), but even cerebellar growth was considerably 'spared' relative to bodily growth.

Brain enzyme activities. Both rehabilitated and undernourished animals at 12 weeks of age had significantly higher AChE concentrations (units/g wet wt) than controls (Table 2); this was true in all regions irrespective of whether the whole homogenates or crude mitochondrial fractions were used. AChE concentrations in brains of 
Vol. 28

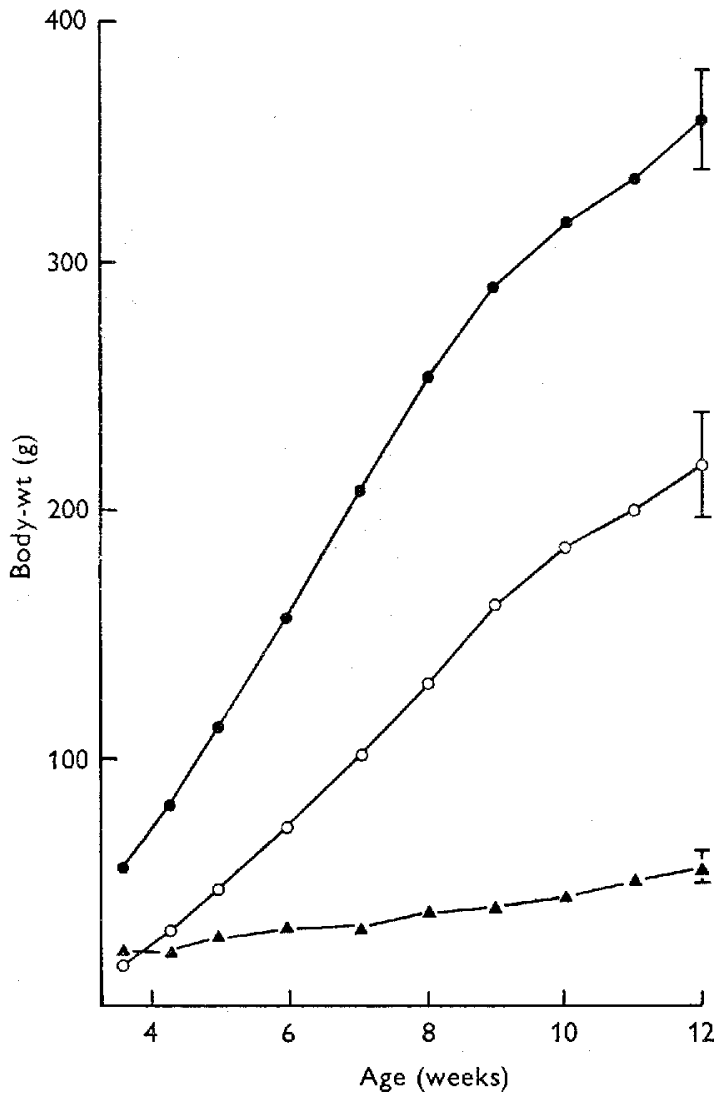

Fig. I. Body growth curves for control (C) rehabilitated (O) and undernourished ( $\mathbf{A}$ ) male rats from weaning. Each point represents the mean for eight animals. Standard deviations, represented as vertical bars, are shown at $\mathrm{i} 2$ weeks.

Table I. Body-weights $(g)$ and brain weights $(g)$ at 12 weeks of age

(Mean values and standard deviations for groups of eight rats; figures in parentheses represent percentage changes from control values)

$\begin{array}{lccc} & \text { Control } & \text { Rehabilitated } & \text { Undernourished } \\ \text { Body-wt } & 360 \pm 21 & 220 \pm 22 & 57 \pm 4 \\ \text { Forebrain wt } & \mathbf{I} \cdot \mathbf{I} 72 \pm 0.057 & (-39 \%) & (-84 \%) \\ \text { Cerebellum wt } & 0.284 \pm 0.016 & 0.968 \pm 0.046 & 0.825 \pm 0.026 \\ & & (-17 \%) & (-30 \%) \\ \text { Brain-stem wt } & 0.209 \pm 0.009 & 0.178 \pm 0.007 \\ & & (-26 \%) & (-37 \%) \\ & & 0.312 \pm 0.013 & 0.270 \pm 0.009 \\ & & (-20 \%) & (-30 \%)\end{array}$

All groups showed highly significant differences $(P<0.001)$ fromall other groups for all measurements. 
Table 2. Acetylcholinesterase activity (units/g wet wt) in brain regions

(Mean values and standard deviations for groups of eight animals; figures in parentheses are changes from control values. One unit represents I nmol subtrate consumed per min)

\begin{tabular}{|c|c|c|c|c|c|c|c|}
\hline \multirow[b]{2}{*}{ Region } & \multirow[b]{2}{*}{$\begin{array}{l}\text { Enzyme } \\
\text { source }\end{array}$} & \multirow[b]{2}{*}{$\begin{array}{l}\text { Contral } \\
\text { (C) }\end{array}$} & \multirow[b]{2}{*}{$\begin{array}{l}\text { Rehabilitated } \\
\text { (R) }\end{array}$} & \multirow[b]{2}{*}{$\begin{array}{l}\text { Under- } \\
\text { nourished (U) }\end{array}$} & \multicolumn{3}{|c|}{$P$ value } \\
\hline & & & & & $\mathrm{C} v \cdot \mathrm{R}$ & $\mathrm{C} v . \mathrm{U}$ & $\mathrm{R} v . \mathrm{U}$ \\
\hline \multirow[t]{2}{*}{ Forebrain } & Whole homogenate & $8333 \pm 634$ & $\begin{array}{c}9259 \pm 42 I \\
(+\mathrm{II} \%)\end{array}$ & $\begin{array}{c}9680 \pm 446 \\
( + \pm 6 \%)\end{array}$ & $<0.005$ & $<0.001$ & NS \\
\hline & $\begin{array}{l}\text { Mitochondrial } \\
\text { fraction }\end{array}$ & $4270 \pm 333$ & $\begin{array}{c}4810 \pm 358 \\
( + \pm 3 \%)\end{array}$ & $\begin{array}{c}5256 \pm 276 \\
(+23 \%)\end{array}$ & $<0.01$ & $<0.00 \mathrm{r}$ & $<0.02$ \\
\hline Cerebellum & Whole homogenate & $2041 \pm 54$ & $\begin{array}{c}2266 \pm 190 \\
( + \pm I \%)\end{array}$ & $\begin{array}{c}2242 \pm 53 \\
(+10 \%)\end{array}$ & $<0.01$ & $<0.001$ & NS \\
\hline \multirow[t]{2}{*}{ Brain stem } & Whole homogenate & $6756 \pm 370$ & $\begin{array}{c}7275 \pm 371 \\
(+8 \%)\end{array}$ & $\begin{array}{c}7642 \pm 410 \\
(+13 \%)\end{array}$ & $<0.02$ & $<0.001$ & NS \\
\hline & $\begin{array}{l}\text { Mitochondrial } \\
\text { fraction }\end{array}$ & $2913 \pm 138$ & $\begin{array}{c}3174 \pm 262 \\
(+9 \%)\end{array}$ & $\begin{array}{c}3260 \pm 204 \\
(+\mathrm{t} 2 \%)\end{array}$ & $<0.05$ & $<0.005$ & NS \\
\hline
\end{tabular}

\section{Table 3. Forebrain enzyme activities (units/mg protein)}

(Mean values and standard deviations for groups of eight rats; each enzyme was assayed on each animal. One unit represents i nmol substrate consumed per min)

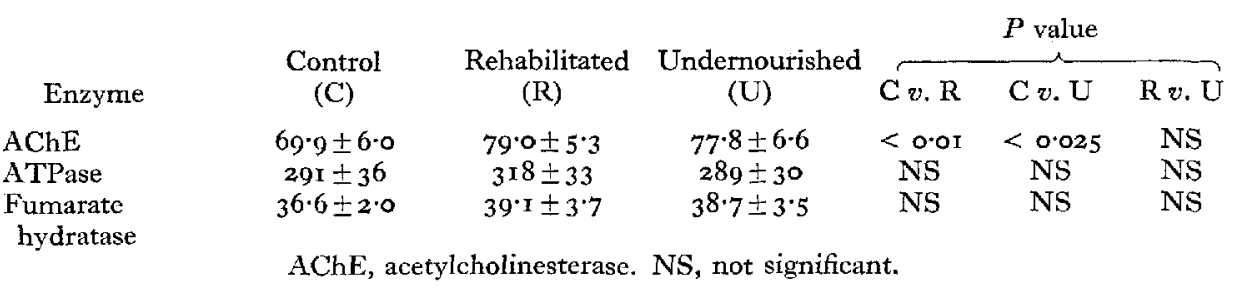

rehabilitated animals were usually intermediate between those of undernourished and control animals, more closely resembling the former.

The total AChE activity (units/region) either in whole homogenates or crude mitochondrial fractions was in the order control $>$ rehabilitated $>$ undernourished; differences were significant for all comparisons within each region. The deficits in total AChE in growth-retarded animals were, however, less than the corresponding deficits in regional weights (Table $\mathrm{I}$ ).

Forebrain AChE activity in terms of tissue protein (units/mg protein) was also raised in growth-retarded animals compared with controls (Table 3), but ATPase and fumarate hydratase were not significantly affected.

\section{DISCUSSION}

The development of AChE activity in rat brain is retarded by undernutrition (Sereni, Principi, Perletti \& Sereni, I 966; Adlard \& Dobbing, I97 a a). Three-week-old growth-retarded animals have decreased concentrations of the enzyme in forebrain and brain stem (Adlard \& Dobbing, 1972). The results reported here suggest that, 
between weaning and adulthood, previously undernourished (rehabilitated) and control groups 'cross over', the former finally having higher than normal AChE concentrations.

There are at least three possible explanations of raised $\mathrm{AChE}$ activity as a result of early nutritional deprivation: (I) altered kinetic properties of the enzyme, (2) a general increase in enzyme concentration within membranes, (3) a 'sparing' of structures in which the enzyme is present relative to those from which it is absent. The third possibility would give the findings a morphological rather than a chemical basis and must be considered in view of the large regional (Friede, 1966) and subcellular (De Robertis, De Iraldi, Arnaiz \& Salganicoff, 1962) variations in AChE distribution. Detailed histological, subcellular distribution and enzymological studies will be required to decide between the various explanations. However, since $\mathrm{AChE}$ is found in high concentrations in nerve-ending particles (which sediment in crude mitochondrial fractions) it may be speculated that the results may represent a 'sparing' of nerve-endings relative to other cell fractions.

We gratefully acknowledge support from the Medical Research Council, the National Fund for Research into Crippling Diseases and the Spastics Society.

\section{REFEREN CES}

Adlard, B. P. F. \& Dobbing, J. (1971 a). Brain Res. 28, 97.

Adlard, B. P. F. \& Dobbing, J. (I 97 I $b$ ). Brain Res. 30, 198.

Adlard, B. P. F. \& Dobbing, J. (1972). Pediat. Res. 6, $3^{8 .}$

Chase, H. P., Dorsey, J. \& McKhann, G. M. (1967). Pediatrics, Springfield 40, 55I.

Cuzner, M. L. \& Davison, A. N. (1968). Biochem. F. 106, 29.

De Robertis, E., De Iraldi, A. P., Arnaiz, G. R. L. \& Salganicoff, L. (1962). F. Neurochem. 9, 23.

Dobbing, J. (1 968). In Applied Neurochemistry p. 287 [A. N. Davison and J. Dobbing, editors]. Oxford: Blackwell.

Dobbing, J. (r972). Ciba Fdn Symp. (In the Press.)

Ellman, G. L., Courtney, K. D., Andres, V. \& Featherstone, R. M. (196r). Biochem. Pharmac. 7, 88. Fonnum, F. (1968). Biochem. F. 106, 401.

Friede, R. L. (1966). Topographic Brain Chemistry p. 237. London: Academic Press.

Lowry, O. H., Roscbrough, N. J., Farr, A. L. \& Randall, R. J. (1951). J. biol. Chem. 193, 265.

Racker, E. (1950). Biochim. biophys. Acta 4, 2 rr.

Sereni, F., Principi, N., Perletti, L. \& Sereni, L. P. (1 966). Biologia Neonat. Io, 254.

Smart, J. L. \& Dobbing, J. (I97I). Brain Res. 28, 85 .

Swanson, P. D., Bradford, H. F. \& McIlwain, H. (r964). Biochem. F. 92, 235. 